\title{
UTILIZATION OF DRYING AIR TEMPERATURE AND RELATIVE HUMIDITY FOR SAVING THE REQUIRED TIME AND ENERGY FOR DRYING ROSEMARY PLANTS
}

\author{
Arafa. G. K.*
}

\begin{abstract}
The purpose of this study is to test and evaluate the effect of drying temperature on the behavior of moisture content and relative humidity of the drying air and drying time of orchid plants at four different levels of temperature. An experimental dryer was designed and installed with local components, which can control the temperature under study to the levels of $\left(35,40,45\right.$ and $\left.50^{\circ} \mathrm{C}\right)$ with a corresponding relative humidity of to the levels of (32.2, 28.3, 24.5 and21.2) respectively. The air speed was adjusted at $(1.5 \mathrm{~m} / \mathrm{s})$ to achieve maximum utilization of energy used in drying. The average primary moisture content of the rosemary was $80 \%$ on a wet basis. There is an inverse relationship between the temperature and relative humidity of the air inside the dryer where the relative humidity of the air decreases from $32.2 \%$ to $21.2 \%$ when the temperature increased from 35 to $50{ }^{\circ} \mathrm{C}$. There is an inverse relationship between temperature and final moisture content values where the final moisture content is reduced from 80 to $32.65 \%$ on a dry basis with temperatures increasing from 35 to $50^{\circ} \mathrm{C}$. There is a difference between the temperature in and out of the drying air and the difference is greater at the beginning of the drying process has decreased to reach the lowest value at the end of the drying process. The highest value of the relative humidity outside of the air was at the beginning of the drying process and it was reduced during the drying process until it reaches its lowest value at the end of the drying process. There is an inverse relation between temperature and drying time, the higher the temperature the lower the drying time.
\end{abstract}

*Res., Ag. Eng. Res. Institute., Ag. Res. Center. 


\section{INTRODUCTION}

$\mathrm{M}$ edicinal and aromatic plants cultivated in all over the world particularly in Egypt for both local consumption and export. The Rosemary is one of the most important aromatic plants in Egypt. Its area is about 1091 feddans, producing about 1951 ton/year from green plants and 29.262 ton essential oil (The CAGMC, Annual Stistical Book 2008). The operation of drying in Egypt is by using natural sun and wind to dry aromatic plants, but low quality and high losses occur because during drying, the aromatic plants are not protected from dust, rain, birds, and insects. Industrial drying by dryers provided high levels of quality and quantities of aromatic plants. The importance of drying aromatic plants and herbs can be used for ethereal perfumes, beautiful preparation industry, agricultural and animal production, sweet and jam industry as natural materials for taste. They are used also for medicine components and medicine industry, which is used for treatments of diseases of humans and animals. Müller and Mühlbauer (1990), the increase in the air temperature from 30 to $50^{\circ} \mathrm{C}$ in drying of chamomile (Chamomilla recutita) reduced drying time from 52 to $3.5 \mathrm{~h}$, causing no significant reduction in oil content essential. It changes between 15 to $25 \%$, independent of drying. Koller and Raghavan (1995) studied the effects of oven drying, freeze drying and microwave drying on the composition of essential oil of thyme (Thymus vulgaris L.). They concluded that the chromatographic profile was shown to be unbalanced in relation to the constituents of the essential oil extracted from fresh plant, especially in relation to the major component, thymol. Costa et al. (1998) found better visual quality in leaves of Guaco (Mikania glomerata Sprengel) when dried in an oven with forced air at $37^{\circ} \mathrm{C}$ than in a chamber with desiccant at ambient temperature. Drying at ambient temperature, the leaves were dark spots, which may indicate the need of short time to dry this specie. Rocha et al. (2000) studied the temperatures of 30, 40, 50, 60 and $70^{\circ} \mathrm{C}$ to dry citronella (Cymbopogon winterianus Jowitt) and concluded that the best results were obtained when the air temperature was $60^{\circ} \mathrm{C}$, because had the highest essential oil content,without affecting the chromatographic profile of the essential oil, in other words, without influencing its quality (Omidbaigi et al., 2004). Radünz (2004), after 
working with drying of mintcommon (Mentha $\mathrm{x}$ villosa Huds), at temperatures between 50 and $70^{\circ} \mathrm{C}$, concluded that the air temperature of $50^{\circ} \mathrm{C}$ is recommended for drying mint-common in order to obtain the highest essential oil content and higher concentration of the main active constituents. Costa et al. (2005), studying two drying types (oven with forced ventilation at $40^{\circ} \mathrm{C}$, and room temperature with dehumidifiers) of lemon grass, concluded that the most abundant component in the essential oil was citral, and had the highest concentrations in the leaves dried in the dehumidifiers. Mendes et al. (2006) investigated the effect of natural and artificial drying on the composition of the essential oil of Cymbopogon nardus and concluded that, especially for this plant, the drying operation did not influence the composition of the volatile compounds. Braga et al. (2005) evaluated the effects of different drying air temperatures $(35,40$, $45,50,55$ and $60^{\circ} \mathrm{C}$ ) on the yield and composition of essential oil from long pepper (Piper hispidinervium c. dc) leaves in a fixed-bed dryer. They observed that the essential oil yield increased twice after the drying process compared with the fresh plant. However, safrole content decreased about $20 \%$ when temperature was above $50^{\circ} \mathrm{C}$. Radünz et al. (2006) used common-mint (M. x villosa Huds),drying it on a fixed-bed dryer with ambient air and air heated to $40,50,60,70$ and $80^{\circ} \mathrm{C}$ and evaluated the essential oil content extracted after drying with that extracted from the fresh plant. Based on the results, it was concluded that the higher content was obtained when the drying process was done with drying air at $50^{\circ} \mathrm{C}$. David et al. (2006) evaluated the influence of the drying air temperature on Ocimum selloi Benth essential oil composition. They observed that the main components of essential oil were elimicin $(69.8 \%)$, trans-caryophyllene $(6.0 \%)$, germacrene D $(3.7 \%)$ and bicyclogermacrene $(3.5 \%)$, and they found that increasing temperature above $40^{\circ} \mathrm{C}$ reduced the levels of the components. Sefidkon et al. (2006) evaluated the influence of drying methods (sun-drying, shade-drying and oven-drying at $45^{\circ} \mathrm{C}$ ) on yield and chemical composition of the essential oil of Satureja hortensis. It could be concluded that drying of aerial parts of $\mathrm{S}$. hortensis in the oven at $45^{\circ} \mathrm{C}$ is most suitable and is recommended for fast drying, and high-oil yield, as well as, for a high-percentage of carvacrol. Soares et al. (2007) studied the influence of 4 drying air 
temperatures $\left(40,50,60\right.$ and $\left.70^{\circ} \mathrm{C}\right)$, in thin layers, and 2 air velocities $(0.9$ and $1.9 \mathrm{~m} \mathrm{~s}-1)$ on the essential oil content of brazilian linalool (O. basilicum L). The higher essential oil contents were obtained in the drying process with an air temperature at $40^{\circ} \mathrm{C}$ and air velocity of $1.9 \mathrm{~m} \mathrm{~s}$ 1. The highest linalool contents were obtained with drying air temperature from 50 to $60^{\circ} \mathrm{C}$ and an air velocity of $1.9 \mathrm{~m} \mathrm{~s}-1$. They concluded that the essential oil chemical composition of $\mathrm{O}$. basilicum L was affected by both temperature and air velocity during drying. Borsato et al. (2009) studied the effect of drying process in a fixed layer at $80^{\circ} \mathrm{C}$ on the yield and chemical composition of chamomile (Chamomilla recutita [L.] Rauschert) essential oil. They concluded that the drying process of chamomile showed reduction essential oil content and chemical composition. Ennajar et al. (2010) used sun-drying, shade-drying and oven-drying at $45^{\circ} \mathrm{C}$ to study the effects on yield and chemical composition of Juniperus phoenicea L. essential oils. Arafa (2001) studied drying of three types of aromatic plants (M. Pulegium, Marjoram, and Peppermint), at different temperatures of $35,40,45,50$, and $60 \mathrm{oC}$ and different air relative humidity of $25,50,65$, and $75 \%$ through fixed temperature $(45 \mathrm{oC})$ and fixed 1.1 $\mathrm{m} / \mathrm{s}$ air velocity.

\section{MATERIAL AND METHODS}

\section{1-Materials:}

\subsection{1-Herbs used in this investigation:}

Rosemary plants terminal steam cutting of $(15 \mathrm{~cm}$ length) and the well rooted vegetative parts (runners) of equal size $(8-10 \mathrm{~cm}$ length, with 5-8 leaves) were used. Rosemary plants. were collected in The samples of plants were obtained from the farm of Medicinal and Aromatic plants Research Department, Dokki, Giza, in 2018 The fresh plant materials were carefully separated into leaves, stems, and mixed of stems and leaves.

\subsection{2-Laboratory drye specifications:}

A laboratory dryer shown in Fig.(1) was used in the present study. It was constructed, assembled and manufactured locally at the workshops of Minofia Governorate to be used for artificial drying of aromatic plants (Rosemary). The experiment all work was carried out in Bhnay village, 
EL-Bagour center, Minofiea Governorate, Egypt in 2018. The dryer consists of three components; forced air unit, an air heating unit and drying unit.

(a) -Forced air unit: This unit consists of a centrifugal fan driven by variable speeds electric motor with maximum power of $1 \mathrm{hp}(3 / 4 \mathrm{~kW})$ at 1200 r.p.m

(b) -Air heating unit: It consists of electric heater, electric switch and air heating tunnel. Electric switch was of variable resistance to control the heating source .It was connected before heaters to change the supply of electric current and provide suitable air heating for the drying process. An electric heater of $1.5 \mathrm{~kW}$ was used to heat air inside the air chamber. Air chamber is cylindrical in shape and made of steel sheet. The electric heater was asscopld situated in the middle of the air chamber.

(c) -Drying unit: It consists of steel sheets and angles of 0.5 meter long, 0.5 meter wide and one meter high. The frame was covered by double layer of steel sheet that contain in between fiber glass as an insulation material to reduce heat losses from the drying unit.

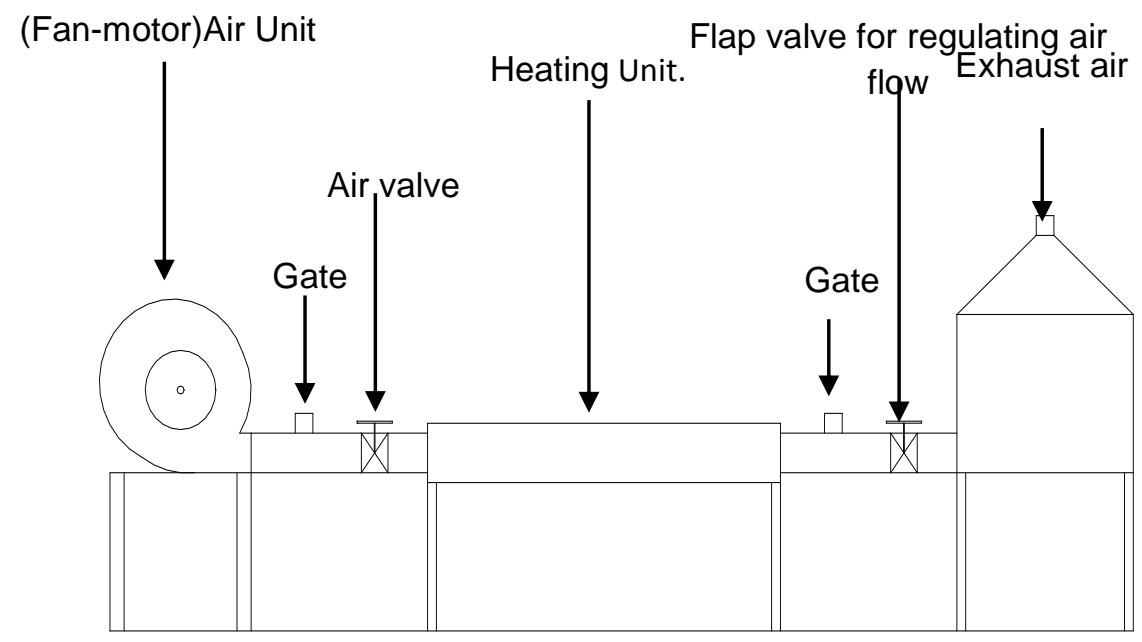

Fig (1): Schematic diagram of experimental

\subsection{3 -Instrumentation:}

(a) - turbometer: A turbometer (Source: U.S.A, type: electronic, model No:5951-75,sensitivity:0.1 m/s.) was used to measure the air velocity during the drying experiments. 
(b) -Digital humidity /temperature meter : It was used to measure the air relative humidity and temperature of drying air during drying process. The instrument has the following specifications: current: consumption approx.7mA, dimension: 200x70x36 mm, weight: 270 g/including battery, sensor type: humidity-precision thin film capacitance sensor, temperature-solid state-sensor, R.H range: 10 to $95 \%$,temp. range:0 to 60 ${ }^{\circ} \mathrm{C}$.

(c) - Stop watch: A stop watch was used for measuring the drying time.

(d) -Electric balance: the electric balance was used for measuring the weight sample of Rosemary plants during drying, rang: 1 to $5 \mathrm{~kg}$, sensitivity: $0.1 \mathrm{~g}$

\section{2-2- Methods:}

\section{2-2 1-The studied variables:}

The following variables were tested to show their effect on the wet basis moisture content of rosemary plant

(a) - Air temperature: Four different air temperature $35,40,45$ and $50{ }^{\circ} \mathrm{C}$

(b) - Air relative humidity: Four different relative humidity levels 32.2, $28.3,24.5$ and $21.2 \%$.

(c) - Drying time: Every hour from 1 to $12 \mathrm{~h}$.

(d) - Air velocity: fixed air velocity of $1.5 \mathrm{~m} / \mathrm{s}$

\section{3 - Calculations:}

\subsection{1-Moisture content; wet basis (M.C.w.b \%):}

The wet basis moisture content was measured for Rosemary plants under test by taking random samples from herbs before drying, separated to be ready for drying and drying it in air forced electric heater at $105{ }^{\circ} \mathrm{C}$ at atmospheric pressure for three hours after measuring its initial moisture content before drying according to Arafa (2001). The moisture content was calculated according to the following equation.

Mcwb $=($ Mwet - Mdry $) /$ Mwet x 100

Where:

$$
\begin{aligned}
& \text { Mcwb }=\text { Moisture content, wet basis } \% . \\
& \text { Mwet }=\text { Mass of wet samples, } g . \text { and } \\
& \text { M dry }=\text { Mass of dry samples, } g .
\end{aligned}
$$




\section{4 -Procedure}

The sample of Rosemary plants (one $\mathrm{kg}$ ) which artificially dried was washed to remove the mud and dirt before entering into the drying unit the moisture content was found by the standard oven method i. e. drying the sample of $10 \mathrm{~g}$ at $105{ }^{\circ} \mathrm{C}$ for three hour (3h). Three samples each of 10 $\mathrm{g}$ were taken to determine the initial moisture content using the procedure suggested by Arafa (2001). Prior to the start the drying test, the dryer was allowed to run for one hour with fixed air velocity of $1.5 \mathrm{~m} / \mathrm{s}$. The airflow was regulated by operating a flap valve installed between the heating unit and the centrifugal fan. The drying air temperature range was between 35 and $50{ }^{\circ} \mathrm{C}$. Drying was continued until the moisture content was in equilibrium with the temperature and relative humidity of the drying air. The start of the drying test was recorded using a stop watch. The room air temperature and relative humidity were recorded. Initially at zero time, the inlet and outlet air temperatures and relative humidity were measured. The sample was dried for $12 \mathrm{~h}$ with a periodic, weighing every 1 hour of the drying process. At the end of the drying test, the moisture content of the dried sample was determined as described by Arafa (2001).

\section{RESULTS AND DISCUSSION}

The most important factors affecting the drying of medicinal and aromatic plants are the temperature and relative humidity of the drying air and the drying time. Tests were performed when the air speed was constant at 1.5 $\mathrm{m} / \mathrm{s}$ these factors significantly determine the continuation or stopping of the drying process under the initial condition and vecyolin the exhaust air until the end of the drying process. It thus conserves the energy used.

\section{1-Effect of temperature on moisture content of Rosemary plant on drying time}

Fig. (2) shows the relationship between temperature and moisture content of rosemary plants. It was found that there is an inverse relationship between temperature and moisture content of rosemary plants as a result of the intersection occurs between them. Both temperature and moisture content of the rosemary plants. Discontinue changing the drying process should be stopped because drying continues consume energy and is not useful. 


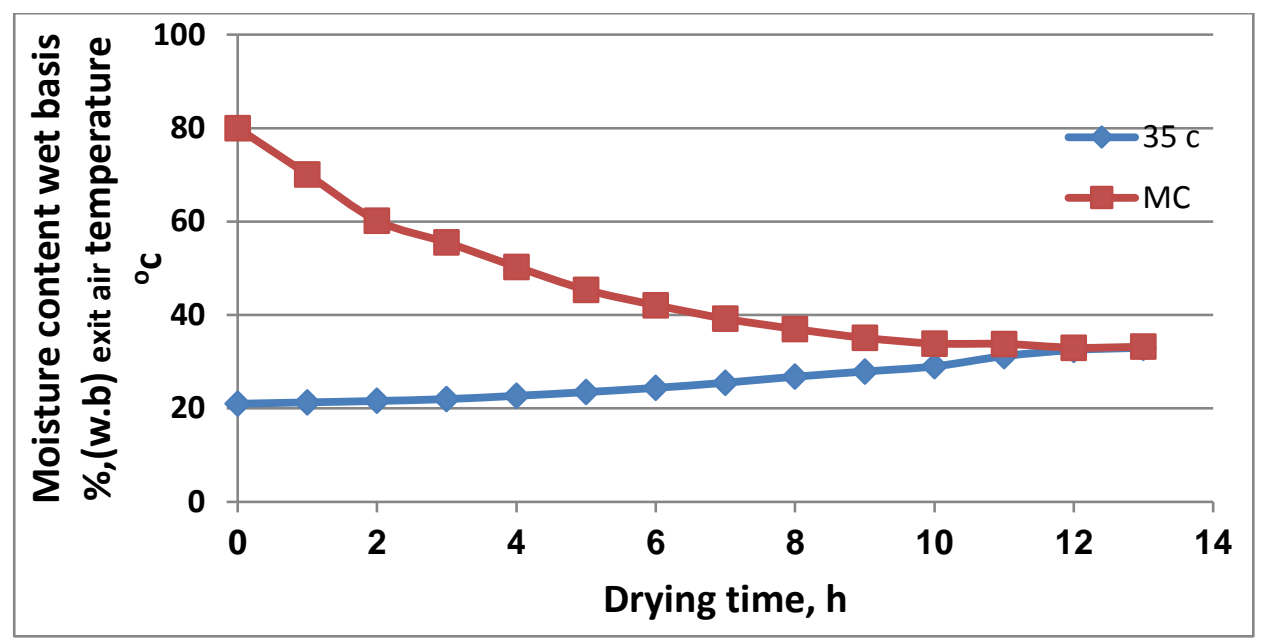

Fig.2 Moisture content wet basis \%,(w.b) temperature ${ }^{\circ} \mathrm{C}$ against drying time, $h$ at $35{ }^{\circ} \mathrm{C}$ air temperature and $1.5 \mathrm{~m} / \mathrm{s}$ air velocity.

Generally, at the beginning of drying, the moisture content is higher and then reduced to the lowest value at the end of drying at all temperatures levels. Also at the beginning of the drying process the exhaust temperature from the dryer is less than the conformance temperature and over time the temperature increases until it reaches the temperature entering the dryer which prove the end of the drying. At this point, an intersection between the moisture content curves occurs with the temperature curve. The intersection point occurs a less time of the normally considered time of drying process. The time of moisture content curve and the temperature curve before the intersection point is significant for conducting the drying process specially at small temperature levels. The area between the moisture content curve and the temperature curve before the turning point is fully used for drying. The total amount of heat is fully used for dehumidification of the plant and the area between the moisture content curve and the temperature curve reflect the effectiveness of temperature in the drying process with minimum energy used. The final moisture of the dried plants at different temperature levels is inversely proportional to the temperature where the final moisture content were $35,28,22$ and $20 \%$ at $35,40,45$ and $50{ }^{\circ} \mathrm{C}$ respectively. If the drying air is used again, its best use is after the intersection point between the moisture content curve and the temperature 
curve. The temperature in the dryer is low at the beginning of the drying process and then increases over time to which the temperature entering the dryer and then stabilized. The drying must stand here because it is useless to continue due to loss of energy. Fig (2) shows that the input temperature of the dryer increases over time and the moisture content of the plant decreases as the dryer temperature is rising from 20 to $33{ }^{\circ} \mathrm{C}$. At this point the moisture content decreases from 80 to only $35 \%$ w.b. There is no intersection between moisture content curve and heat curve to increase humidity, decrease temperature and use full heat in drying.

Fig. (3) shows that the temperature increases within the dryer until it approaches the inlet air temperature, which reaches $40{ }^{\circ} \mathrm{C}$, where it increases from 27 to $38{ }^{\circ} \mathrm{C}$ and the moisture content decreases from 80 to $28 \%$, at this point the intersection occurs between the moisture content curve and the temperature curve after 8 hours at $32 \%$ moisture content 32 ${ }^{\circ} \mathrm{C}$ drying air temperature. This means that the full amount of heat is used before the intersection.

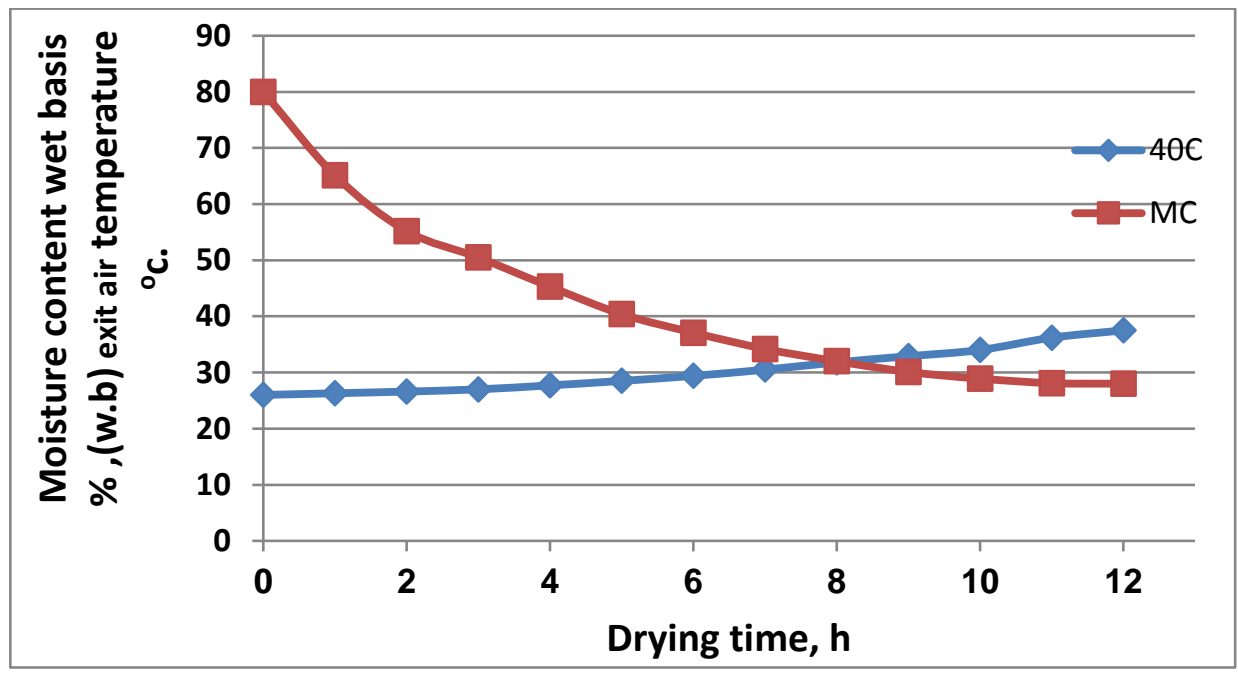

Fig.3 Moisture content wet basis \%,(w.b) temperature ${ }^{\circ} \mathrm{C}$ against drying time, $h$ at $40{ }^{\circ} \mathrm{C}$ air temperature and $1.5 \mathrm{~m} / \mathrm{s}$ air velocity

Fig. (4) shows that the temperature increases within the dryer until approaching the temperature of the inlet air, which was $45^{\circ} \mathrm{C}$, the exhaust temperature rises from 30 to $42{ }^{\circ} \mathrm{C}$, while moisture content decreases 
from 80 to $22 \%$ and the intersection point was ocured after 5 hours at $35 \%$ humidity and $35^{\circ} \mathrm{C}$. This means that not all heat was used.

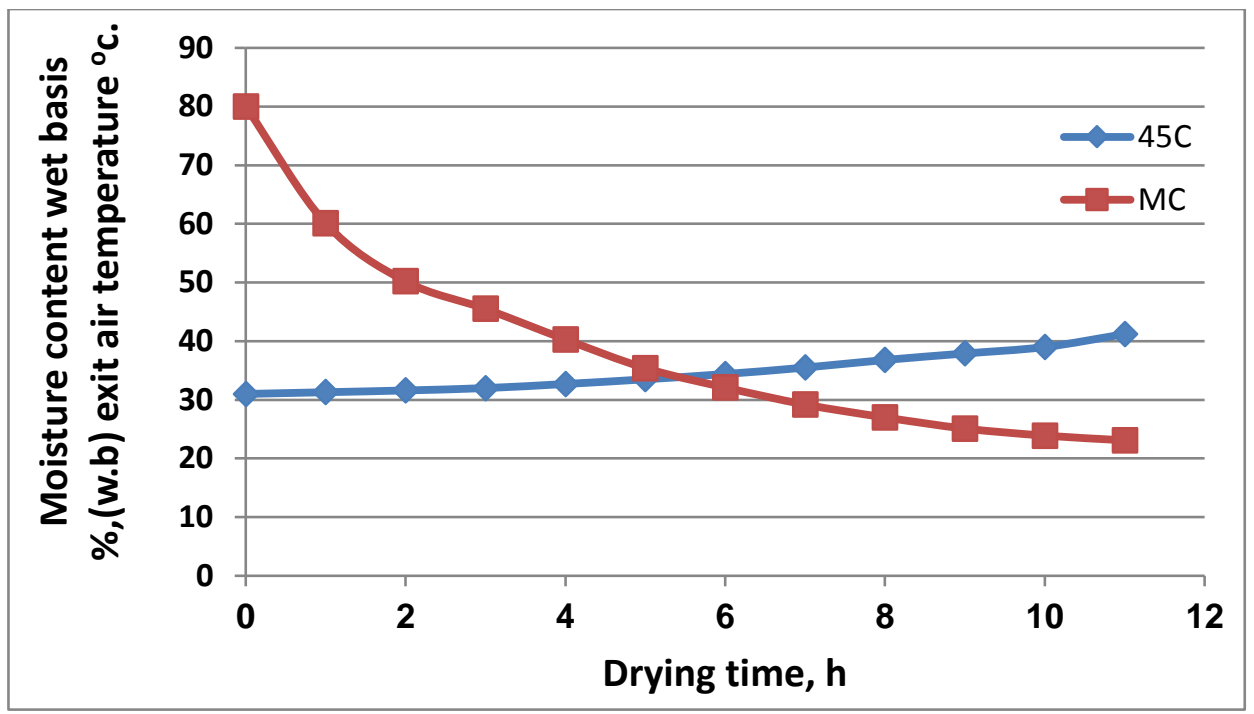

Fig.4 Moisture content wet basis \%,(w.b) temperature ${ }^{\circ} \mathrm{C}$ against drying time, $h$ at $45^{\circ} \mathrm{C}$ air temperature and $1.5 \mathrm{~m} / \mathrm{s}$ air velocity.

Fig. (5) Shows that the air temperature increases until it approaches the drying temperature of $50{ }^{\circ} \mathrm{C}$ (from 35 to $46{ }^{\circ} \mathrm{C}$ ). The moisture content also decreases from 80 to $20 \%$ and the junction point was occurred after 3.5 hours at moisture content of $38 \%{ }^{\circ} \mathrm{C}$ and $38{ }^{\circ} \mathrm{C}$. This means that not all heat was used and benefits of energy was less than the expected level and the air should be reoyeld for maximum utilization of its heat energy.

\section{2 -Effect of moisture content of Rosemary plant on relative humidity of drying air.}

Fig. (5) Shows the relationship between the moisture content of the Rosemary plants and the relative humidity of the exhaust drying air outside the dryer. It was found that there is a direct relationship between the moisture content of the Rosemary plants and the relative humidity of the exhaust air outside the dryer. As a result, thin the relative humidity of the air outside the dryer approached the any reduction of moisture content, level of initial condition of air interlace to the drying process should stopped because continuous of drying consumes energy without 
Fig. (6) Shows the relationship between moisture content of the Rosemary plants and the relative humidity of the air outside the dryer.

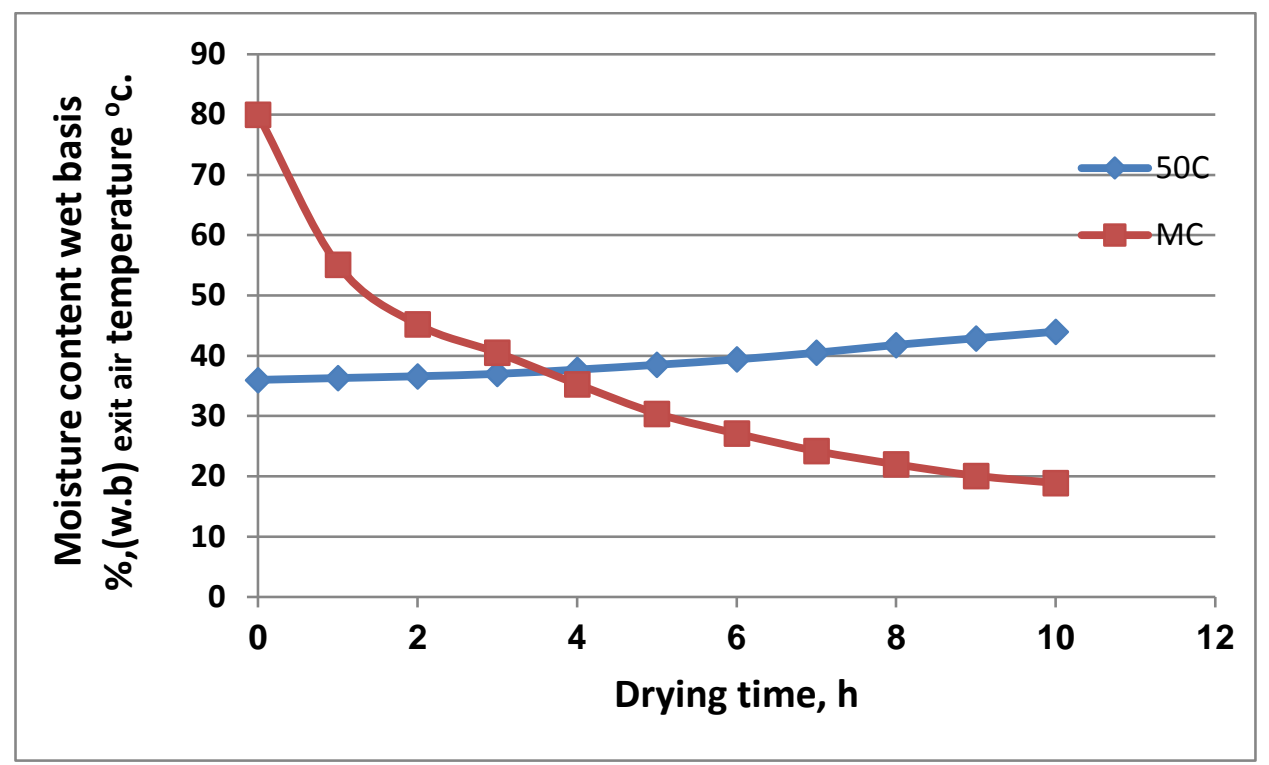

Fig.5 Moisture content wet basis \%,(w.b) temperature ${ }^{\circ} \mathrm{C}$ against drying time, $h$ at $50{ }^{\circ} \mathrm{C}$ air temperature and $1.5 \mathrm{~m} / \mathrm{s}$ air velocity.

There is a direct relationship between moisture content of the plant and relative humidity of the air outside the dryer as a result there is no intersection between them. In Fig. (6) The beginning of the experiment, the moisture content of plants was $80 \%$ and the relative humidity of the air outside the dryer was $118 \%$. Meanwhile the air relative humidity decreases due to heating process and starts to increase at the exhaust air due to moisture absorption from the plants until the moisture content approaches $33 \%$ and the relative humidity increased to $36 \%$ and the temperature decreased from $35^{\circ} \mathrm{C}$ to $50^{\circ} \mathrm{C}$ The moisture content of the plant is reduced and the relative humidity of the air outside of the dryer poll owing this condition. there was no decrease in the moisture content over time thus the drying process must be stopped similar results were obtained for the drying temperatures of 40,45 and $50{ }^{\circ} \mathrm{C}$ as shown in figs.(7 to 9) respectively. In general the relative humidity curve does not intersect with moisture content of the plants during the drying process. 


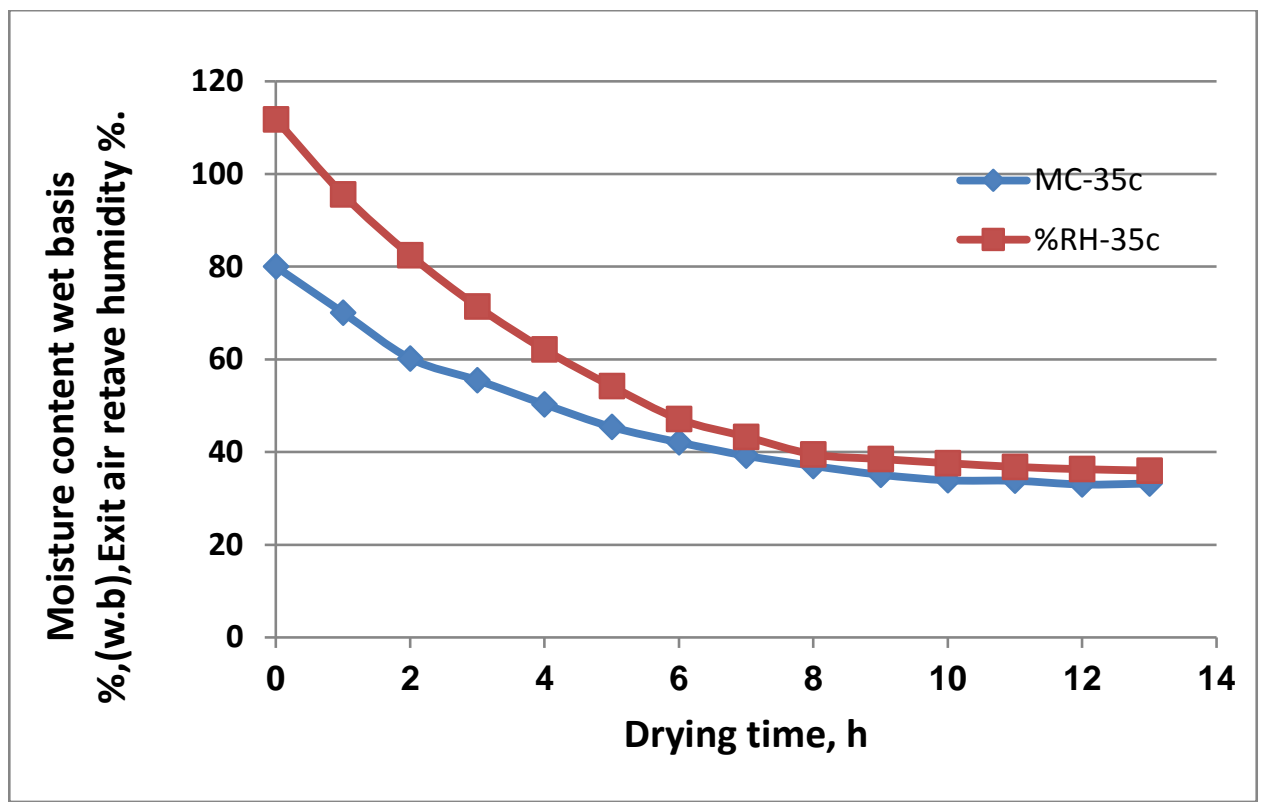

Fig.6 Moisture content wet basis \%,(w.b),exit air relative humidity \% against drying time at $35{ }^{\circ} \mathrm{C}$ air temperature and $1.5 \mathrm{~m} / \mathrm{s}$ air velocity.

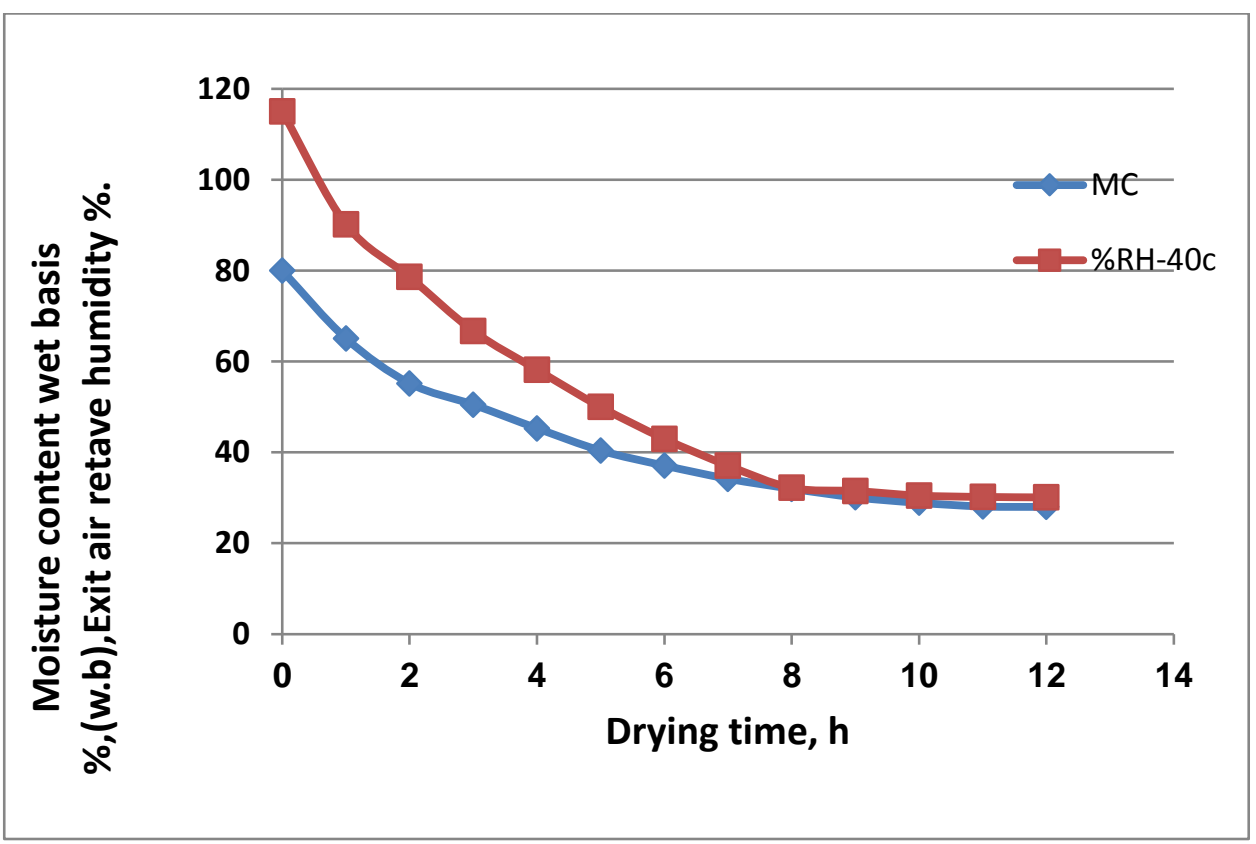

Fig.7 Moisture content wet basis \%,(w.b),exit air relative humidity \% against drying time at $40{ }^{\circ} \mathrm{C}$ air temperature and $1.5 \mathrm{~m} / \mathrm{s}$ air velocity. 


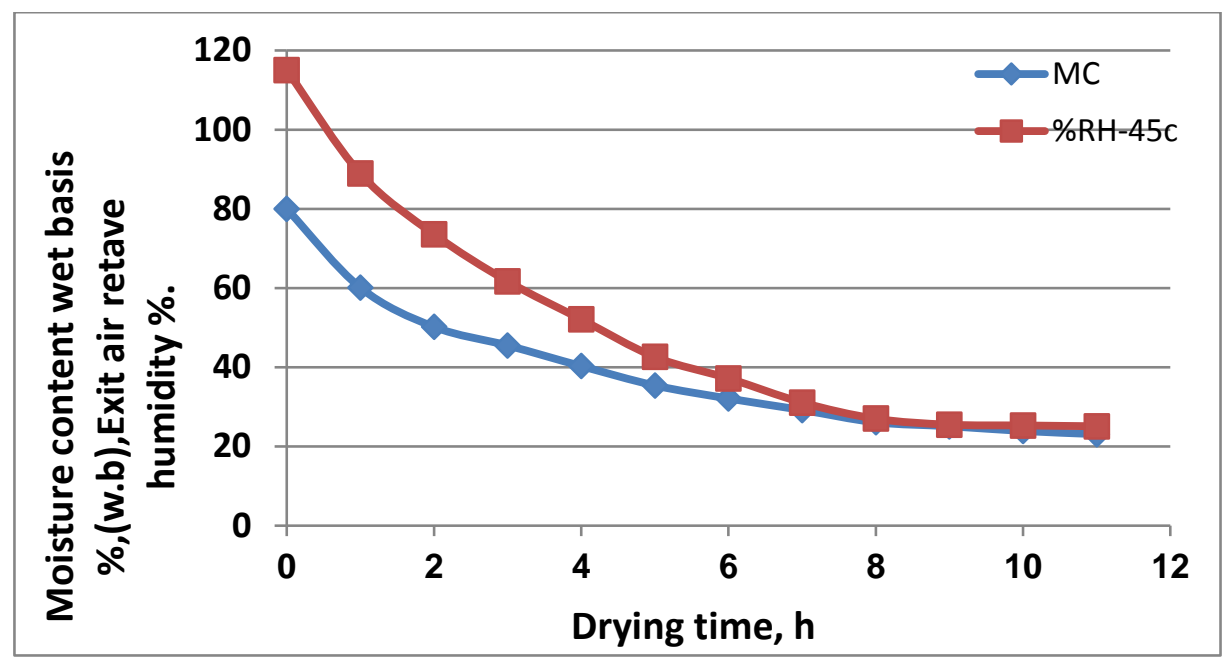

Fig.8 Moisture content wet basis \%,(w.b),exit air relative humidity \% against drying time at $45^{\circ} \mathrm{C}$ air temperature and $1.5 \mathrm{~m} / \mathrm{s}$ air velocity.

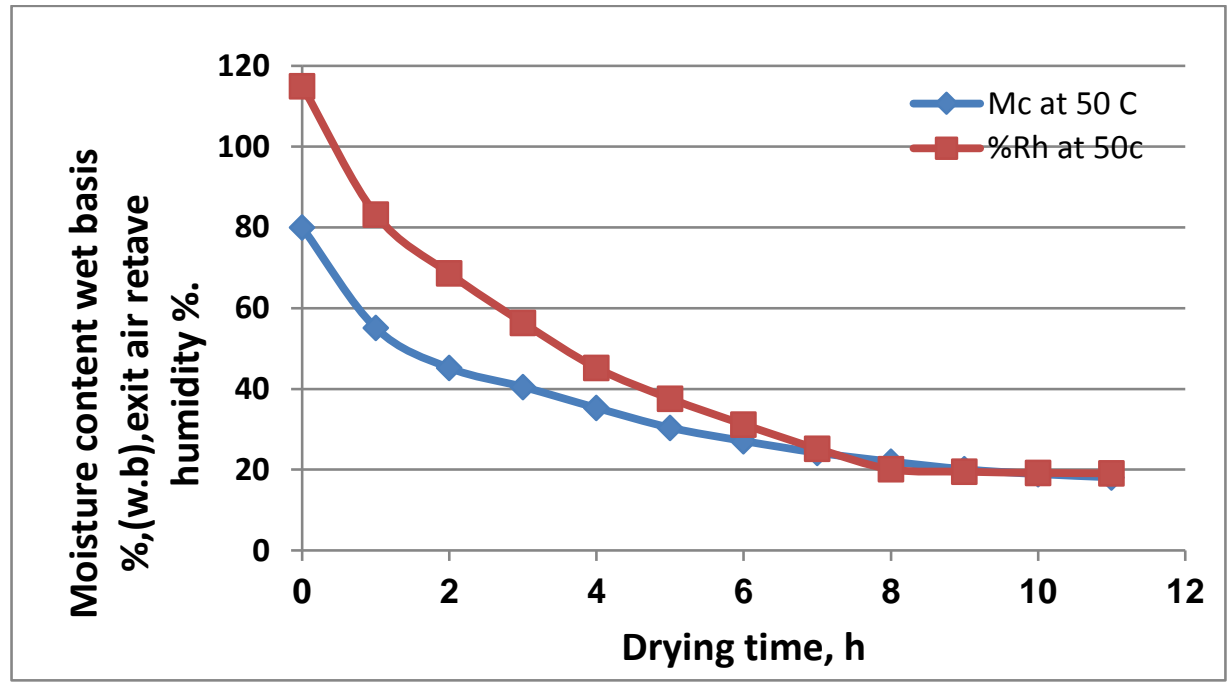

Fig.9 Moisture content wet basis $\%,(w . b)$, exit air relative humidity $\%$ against drying time at $50{ }^{\circ} \mathrm{C}$ air temperature and $1.5 \mathrm{~m} / \mathrm{s}$ air velocity.

\section{CONCLUSION}

From the previous results the following conclusions are derived:

1- There is an inversely relation between temperatures and relative humidity of air.

2- At the start of drying process, the relative humidity of outlet drying air was higher while it was decreased at the end of drying process. 
3- The difference between the inlet and outlet air temperatures was higher at zero time, and then it was decreased until it reached a minimum value at the end of the drying process.

4- Both the outlet air temperature and relative humidity could be used as indicators for stopping the drying process and shifting the drying process to the exhaust air .recycling system to save energy.

\section{REFERENCE:}

Arafa, G. K. (2001). "Factors affecting drying aromatic plants". Ph.D Th., Fac. of Agric., Al-Azhar Univ., Egypt: 99-105.

Borsato, A.V, L. Doni-Filho, M. Rakocevic, L.C. Côcco and E.C. Paglia (2009). Chamomile essential oils extracted from flower heads and recovered water during drying process. J. Food Process. Preserv., 33: $500-512$.

Braga, N.P, M.A. Cremasco and R.Valle (2005). The effects of fixed-bed drying on the yield and composition of essential oil from long pepper (Piper hispidinervium c. dc) leaves. Braz. J. Chem. Eng., 22: 257-262.

CAGMC (Centeral Authority for General Mobilization and Statistics). (2008). "The Annual Stistical Book for A.R.E.:7".

Costa, C.C, V.W.D. Casali and J.A.B. Macedo (1998). Secagem, embalagem equalidade da matéria prima de guaco (Mikania glomerata). In:Workshop de Plantas Medicinais de Botucatu, 1998, Botucatu. Anais... SP: UNESP, p. 35.

Costa, L.C.B., R.M. Corrêa, J.C.W. Cardoso, J.E.B.P. Pinto, S.K.V. Bertolucci, Ferri PH (2005). Drying and fragmentation of the dry matter yield and composition of essential oil of lemongrass. Braz. Horticulture, 23:956-959.

David, E.F.S., M. Pizzolato, R. Facanali, Morais LAS AF Ferri, M.O.M. Marques and L.C. Ming (2006). Influence of drying temperature on yield and chemical composition of essential oil of Ocimum selloi Benth. J. Med. Plants Res., 8: 66-70.

Harbourne N, E. Marete, J.C. Jacquier and D. O'riordan (2009). Effect of drying methods on the phenolic constituents of meadowsweet (Filipendula ulmaria) and willow (Salix alba). Food Sci. Technol., 42:1468-1473. 
Koller, W.D. (1995). Problems with flavour of herbs and spices. Frontiers of flavor, ed. G, Charalambous, Elsevier, Amsterdam, pp. 123-132.

Mendes M.F, L.A. Calçada, G. Reis and D.A. Laranja (2006). Study of the Effect of Drying on natural and forced convection in the Composition of the essential oil of citronella (Cymbopogon nardus). Magazine. Braz. Plants Med., 8: 47-51.

Müller, J. and W. Mühlbauer (1990). Effects of drying on the essential oil of Chamomile recutita. In: International Joint Symposium of: Biol. Chem. Active Natural Substances. Bonn. Anais, p. 155.

Radünz, L.L. (2004). Dried rosemary pepper, and mint together on guaco different temperatures and its influence on the quantity and quality of active ingredients. PhD dissertation, University of Viçosa, Viçosa, Brazil.

Radünz, L.L., E.C. Melo, L.C.A. Barbosa, R.H.S. Santos, F.F. Barbosa and A.P. Martinazzo (2006). Influência da temperatura do ar secagem no rendimento do óleo essencial d hortelã-comum (Mentha x villosa Huds). Eng. Agric., 14: 250-257.

Radünz, L.L., E.C. Melo, P.A.Berbert, L.C.A. Barbosa, R.H.S. Santos and R.P. Rocha (2003). Influence of drying air temperature on the amount of essential oil extracted from guaco (Mykania glomerata Sprengel). J. Storage, 28: 41-45

Radünz, L.L., E.C. Melo, M.C. Machado, R.R. Santos and R.H.S. Santos (2001). Thin layer drying of leaves of Lippia sidoides Cham. In: Brazilian Congress of Agric.Eng. Proc., Foz do Iguacu: CONBEA, CD-ROM.

Radünz, L.L., E.C. Melo, P.M.Martins, R.H.S. Santos, R.R. Santos and M.C. Machado (2002a). Dried rosemary peppermint (Lippia sidoides Cham.) In fixed bed dryer. J. Med. Plants, Botucatu, 5: 79-82.

Rocha, S.F.R., L.C. Ming and M.O.M. Marques (2000). Influence of five drying temperatures on the yield and composition of essential oil of citronella (Cymbopogon winterianus Jowitt). J. Med. Plants, 3: 73-78.

Soares, R.D., M.A.Chaves, A.A.L. da.Silva, M.V. Silva and B.S. Souza (2007). Influence of temperature and SPEED da do na ar secagem of 7084 J. Med. Plants Res.

The CAGMC, Annual Stistical Book 2008. 
PROCESS ENGINEERING

الملخص العربيى

الاستفادة من درجة الحرارة والرطوبة النسبية لهواء التجفيف في توفير الزمن التبان والطاقة اللازمة لتجفيف نباتات الحصالبان

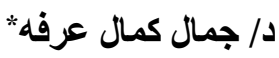

الغرض من هذه الدراسة هو در اسة امكانية استخدام كل من درجة حرارة والرطوبة النسبية

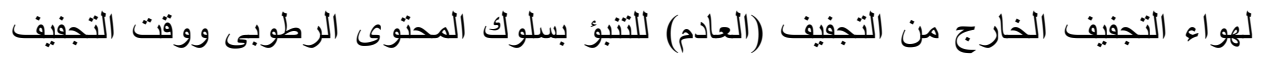
لنبات حصالبان عند أربعة مستويات مختلفة من درجة الحرارة بواسطة مجفف تجريبي تم

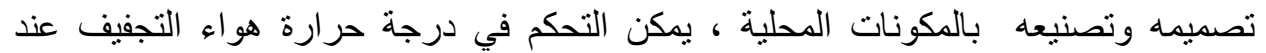

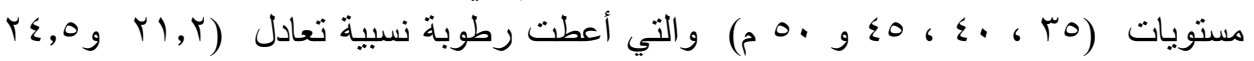

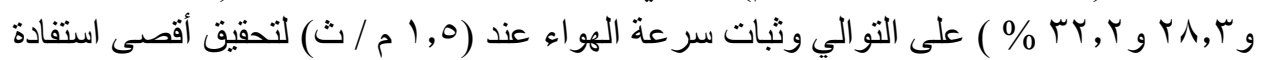

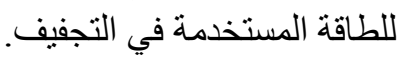

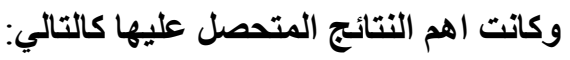

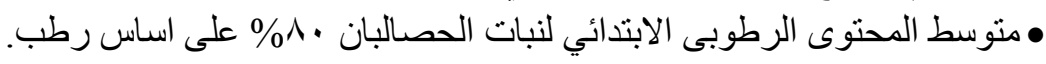

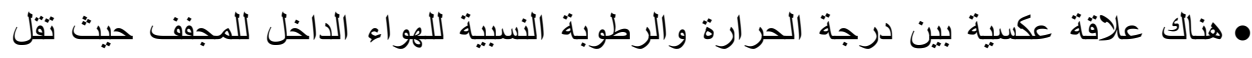

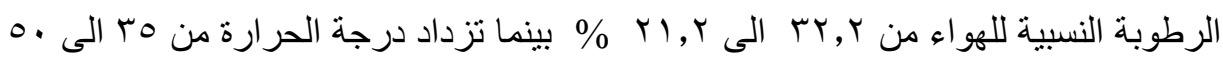

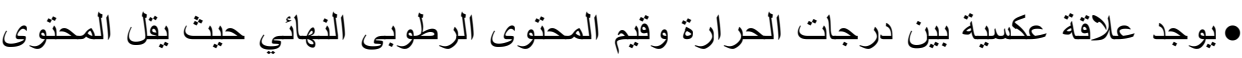

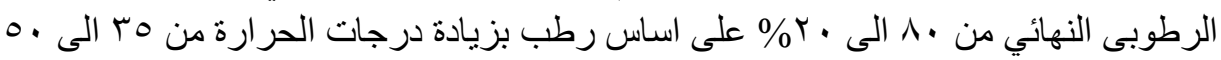

درجة منئوية.

• يوجد فرق بين درجة الحرارة الداخلة والخارجة لهو اء التجفيف ويكون الفرق اكبر عند بداية

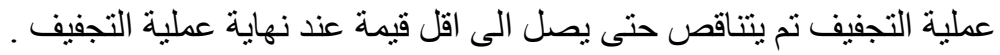

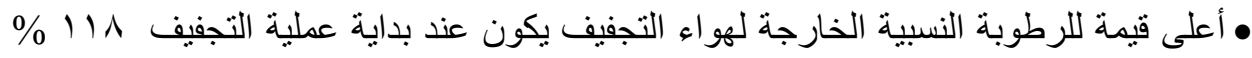
و تقل أثناء التجفيف حتى تصل الى أقل قيمة لها عند نهاية عملية التجفيف حيث تقترب قيمة

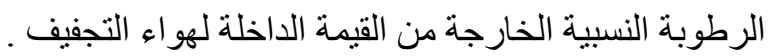
• يوجد علاقة عكسية بين درجات الحرارة وزمن التجفيف فكلما زادت درجات الحر ارة كلما قل لقل زمن التجفيف.

•يحدث تقاطع و انقلاب لمنحنى المحتوى الرطوبي مع منحنى درجة الحرارة وهذا التقاطع يحدث

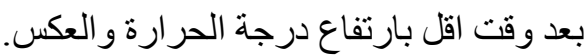

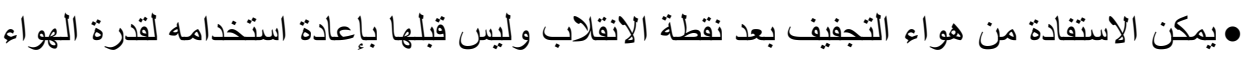
على حمل بخار الماء الناتج من تجفيف النبات مما يقلل من الطاقة المستهلكة فى عملية التجفيف خاصة خلال المرحلة الاخيرة والتي تستغرق وقت زائد بالإضافة الى زيادة فى نى استهلاك الطاقة.

*باحث أول - معهد بحوث الهندسة الزراعية ـ مركز البحوث الزراعية ـ دقي - جيزة - مصر. 